\title{
Potential Role of Mitochondrial Dysfunction in Diabetic Hypertriglyceridemia
}

\author{
Parihar Mordhwaj ${ }^{2}$, Dmitry Litvinov ${ }^{1}$, Sainath Babu ${ }^{2}$, Chandrakala Aluganti Narasimhulu $^{1}$ and Sampath \\ Parthasarathy ${ }^{1 *}$
}

${ }^{1}$ Burnett School of Biomedical Sciences, University of Central Florida, USA

${ }^{2}$ Ohio State University Medical Center, USA

Submission: April 13, 2017; Published: May 30, 2017

*Corresponding author: Sampath Parthasarathy, PhD, MBA, Burnett School of Biomedical Sciences, University of Central Florida, 6900 Lake Nona Blvd, Orlando, FL 32827, USA, Tel: +1-(407)-266-7121; Fax: +1-407-266-7002; Email: spartha@ucf.edu

\begin{abstract}
Type 2 diabetes patients have increased oxidative stress and hypertriglyceridemia. We tested the hypothesis that these two are related and the latter could be the result of peroxide-mediated mitochondrial dysfunction and increased acetate production. Treatment of isolated liver mitochondria or primary hepatocytes with oxidized linoleic acid (LOOH) or hydrogen peroxide $\left(\mathrm{H}_{2} \mathrm{O}_{2}\right)$ resulted in a drastic decrease in activities of pyruvate dehydrogenase (PDHC), aconitase and $\alpha$-ketoglutarate dehydrogenase (KDHC). In contrast, the incorporation of 14C-acetate into lipids was not affected by peroxides suggesting that fatty acid synthesis was not affected. The livers of Db/db diabetic mice showed reduced enzyme activities as compared to control non-diabetic mice. In vitro reaction of pyruvate in the presence of $\mathrm{LOOH}_{0}$ or $\mathrm{H}_{2} \mathrm{O}_{2}$ showed that pyruvate was non-enzymatically converted to acetate together with the release of carbon dioxide $\left(\mathrm{CO}_{2}\right)$.

These results show that diabetic mice may convert more pyruvate non-enzymatically into acetate in the cytoplasm in the presence of peroxides. In addition, mitochondria in diabetic state may have poor capacity to utilize acetate by TCA cycle to generate energy. Combined with the findings that peroxides did not affect acetate incorporation of acetate into fatty acids, one could expect a net increase in fatty acid triacylglycerol (TG) production.

Abbreviations: EDTA: Ethylene Diamine Tetraacetic Acid; EGTA: Ethylene Glycol-Bis ( $\beta$-aminoethyl Ether)-N,N,N'N'-Tetraacetic Acid; FCCP: Carbonyl Cyanide-P-Trifluoromethoxy Phenylhydrazone; HBSS: Hanks Balnced Salt Solution; HNE: Hydroxy Non Enal; KDHC: A-Ketoglutarate Dehydrogenase; LMB: Leukomethylene Blue Reaction; LOH: Lipid Hydroxide; LOOH: Lipid Peroxide; MSH: Mannitol Sucrose Hepes; NADH: Nicotinamide Adenine Dinucleotide Hydrogenase; NMR: Nuclear Magnetic Resonance; PBS: Phosphate Buffer Saline; PDHC: Pyruvate Dehydrogenase; RNS: Reactive Nitrogen Species; ROS: Reactive Oxygen Species; TBARS: Thiobarbituric Acid Reactive Substances; TCA: Tricarboxylic Acid Cycle
\end{abstract}

\section{Introduction}

Increased oxidative stress observed in both clinical and experimental diabetes mellitus has been implicated in the etiology of chronic diabetic complications [1-4]. Hyperglycemia leads to an increase in lipid peroxidation in diabetic patients and animals reflecting a rise in reactive oxygen species production [5-8]. Association of diabetic pathology to mitochondrial dysfunction and oxidative stress have been well documented [9-12]. Various studies point to generalized mitochondrial dysfunction in type 2 diabetes patients [13]. For example, mitochondria of type 2 diabetes patients have been shown to possess reduced electron transport chain capacities and reduced citrate synthase activity [14]. Type 2 diabetes patient's show reduced fatty acid oxidative capacities [15]. Free fatty acid levels are increased together with decreases in fat oxidative capacity in obese, and diabetic patients, and in time this can result in accumulation of fatty acids and acyl glycerols in tissues $[13,16,17]$. Under both normal and pathological conditions, mitochondria are considered as the major endogenous source of ROS [18-20]. During normal metabolism $1-2 \%$ of the electrons that flow into the respiratory chain catalyze the incomplete reduction of $\mathrm{O}_{2}$ generating superoxide anion and hydrogen peroxide. However, under certain pathophysiological conditions the generation of these oxidants dramatically increases, leading to an imbalance between the pro-oxidant and the antioxidant systems. In addition, the high content of polyunsaturated fatty acids in mitochondrial membranes enhances mitochondrial susceptibility to lipid peroxidation, leading to alterations in major enzymes involved in energy production. Liver is heavily dependent on mitochondrial oxidative catabolism for the majority of their ATP requirements. 
Elevated levels of ROS in liver cells are particularly dangerous because they mediate mitochondrial damage, which in turn can generate further oxidative stress in the cells [21]. Fatty acids are particularly sensitive to ROS/RNS oxidation, resulting in the formation of lipid peroxides, which are cytotoxic and lead to free-radical damage to other lipids, proteins and DNA [13].

Lipid abnormalities are commonly associated with diabetes, especially high risk for hyperlipidemia, most commonly in the form of elevated triacylglycerol levels and decreased highdensity lipoprotein (HDL) levels. The most important pathogenic mechanisms, such as increased oxidative stress and increase free fatty acids and triacylglycerols followed by inactivation of mitochondrial enzymes have been identified in experimental studies [4,22-27]. Although multiple oxidant moieties may participate, there is in vitro and ex vivo evidence to support a role for superoxide anion and $\mathrm{H}_{2} \mathrm{O}_{2}$ in the pathogenesis of vascular dysfunction, lipid peroxidation, and formation of glycooxidation products in diabetes [23,26-30]. Various markers of oxidative stress such as increases in oxidized lipoproteins, red cell membrane lipid peroxidation, advanced glycation end products have been documented in blood and tissues of human and experimental diabetic subjects [31-34].

Recent studies shown defects in TCA cycle enzymes are associated with accumulation of very long chain fatty acids and may be accompanied by alterations in the intracellular pool of fatty acid and fatty acyl CoAs, which are known to alter mitochondrial function [35]. Most importantly, mitochondrial alterations in TCA cycle enzymes directly cause defects in electron transport chain (ETC). The pyruvate dehydrogenase complex (PDHC) is a mitochondrial matrix enzyme located exclusively in the mitochondrial matrix that catalyzes the oxidative decarboxylation of pyruvate and represents the sole bridge between anaerobic and aerobic cerebral energy metabolism. $\alpha$-Ketoglutarate dehydrogenase complex (KGDHC) located in the inner mitochondrial matrices is crucial in the cellular production of reducing equivalents (NADH) and in the maintenance of the mitochondrial redox state [36]. Both pyruvate dehydrogenase [37] and $\alpha$-Ketoglutarate dehydrogenase [38] are highly susceptible to oxidants inactivation in vitro. Aconitase contains an (4Fe-4S) cluster and is present in two isoforms. The mitochondrial isoform catalyzes the conversion of citrate to isocitrate in the tricarboxylic acid (TCA) cycle, and the cytosolic isoform is involved in iron metabolism [39]. The (4Fe-4S) cluster confers a marked sensitivity to oxidative stress, and the enzyme is inactivated by reactive oxygen species (ROS) [40-42].

Because mitochondria are a site of free radical production and oxidative damage in diabetes $[43,44]$, it is likely that free radical events contribute to declines in mitochondrial function in those subjects. Since mitochondria are the major cellular site involved in fatty acid metabolism, and the main source of reactive oxygen species (ROS), they could play a key role in fat storage and related complications. However, only limited data exist on the involvement of the mitochondrial compartment in this process.

The present study show increased oxidative stress in diabetic compared to age matched normal mice. Diabetic mice show an inactivation of mitochondrial energy producing enzymes. In addition, these mitochondrial enzymes are very susceptible to inactivation by $\mathrm{LOOH}$ (HPODE) or $\mathrm{H}_{2} \mathrm{O}_{2}$. There is little doubt that one of the most reactive products of fat oxidation is lipid hydroperoxide. Our in vitro studies show that under oxidative stress pyruvate is converted non-enzymatically into acetate that further converted into free fatty acids and triacylglycerols. The goals of this study were to

(i) Determine the mechanism of increased production of free fatty acids and triglycerides in diabetic subjects and

(ii) To identify mitochondrial enzymes inactivated in diabetes under oxidative influence of $\mathrm{LOOH}$ or $\mathrm{H}_{2} \mathrm{O}_{2}$.

\section{Materials and Methods}

\section{Animals}

Male BKS.Cg-m +/+ Lepr ${ }^{\mathrm{db}} / \mathrm{J}$ (Db/db) mice (Jackson Laboratories) of 7-9 months of age were housed in a temperature controlled room with $12: 12 \mathrm{hr}$ light cycle and maintained with access to food and water ad libitum. Db/db mice have a spontaneous Leprdb mutation and develop hyperinsulinemia, hyperglycemia and obesity by 1 to 2 months of age. Aged matched, C57BKS/J mice were used as controls (BKS). All procedures were conducted with the approval of the Institutional Animal Care and Use Committee of the Ohio State University, Columbus, OH, USA and in accordance with National Institutes of Health Guidelines for the Care and Use of Laboratory Animals. Blood glucose was checked via tail stick with a freestyle glucose monitor in order to verify the presence of hyperglycemia in the $\mathrm{Db} / \mathrm{db}$ mice.

\section{Isolation of mitochondria}

Liver mitochondria were isolated from male BKS.Cg-m +/+ Leprdb/J (Db/db) or C57BKS/J mice and Sprague-Dawley rats by differential centrifugation and purified by Percoll purification as described [45]. In brief, liver was removed, washed, and homogenized in MSH EDTA (mannitol, 220mM; sucrose, $70 \mathrm{mM}$; HEPES, 5mM; EDTA, $1 \mathrm{mM}$; pH 7.40). The homogenate was centrifuged at $1,000 \mathrm{x}$ g for $10 \mathrm{~min}$, and the supernatant was re-centrifuged at $10,000 \times \mathrm{g}$ for $10 \mathrm{~min}$ to obtain crude mitochondrial fraction. The enriched mitochondrial pellet was layered on a Percoll solution (25\%) and centrifuged for $30 \mathrm{~min}$ at $100,000 \times \mathrm{g}$. The middle layer was extracted and washed twice in MSH (mannitol, 220mM; sucrose, 70mM; HEPES, 5mM; $\mathrm{pH} 7.40$ ) and centrifuged for $10 \mathrm{~min}$ at $10,000 \times \mathrm{g}$. The purified mitochondria pellet was resuspended in $0.5 \mathrm{ml} \mathrm{MSH}$ and the purity of the mitochondrial preparation was determined. All steps were carried out at $4{ }^{\circ} \mathrm{C}$. Purity of the isolated mitochondria was assessed by measuring cytochrome a using $\varepsilon_{605-630 \mathrm{~nm}} 12 \mathrm{mM}^{-1}$ $\mathrm{cm}^{-1}$ and by measuring transmembrane potential that is rapidly 
reversed by the uncoupler FCCP. Only mitochondria with less than $5 \%$ impurity were used.

\section{Human HepG2 culture and treatments}

Human HepG2 cells (ATCC) were cultured in DMEM containing $10 \%$ fetal bovine serum, $2 \mathrm{mM}$ glutamine, 100 units $/ \mathrm{ml}$ penicillin and $100 \mu \mathrm{g} / \mathrm{ml}$ streptomycin and $4.5 \mathrm{mg} / \mathrm{L}$ $\mathrm{D}$-glucose. The cells were cultured in $75 \mathrm{~cm}^{2}$ flask s for 5 days at $37{ }^{\circ} \mathrm{C}$ under a humidified atmosphere of $95 \%$ air and $5 \% \mathrm{CO}_{2}$ to about $80 \%$ confluence. Cells were treated with $50 \mu \mathrm{M} \mathrm{LOOH}$ and $1 \mathrm{mM} \mathrm{H}_{2} \mathrm{O}_{2}$ for a period of 4 hours. After treatment, cells were washed and supplemented with fresh DMEM and incubated with $\left({ }^{13} \mathrm{C}\right)$ Na-Acetate $(1 \mathrm{mM})$ for 2 hours. At the end of incubation, the medium was aspirated, cells were washed twice with PBS. For the determination of de novo fatty acid synthesis, cells were scrapped from flasks, homogenized with glass homogenizer and protein content was assayed by Bradford method (1976) [46]. The cells were saponified with aqueous $\mathrm{KOH}$ at $37^{\circ} \mathrm{C}$ for $120 \mathrm{~min}$. The total fatty acids were extracted with chloroform. Fatty acid synthesis was determined by LC/MS.

\section{Liver perfusion and culture of primary hepatocytes}

Sprague-Dawley rats were anesthetized by intraperitoneal injection of pentobarbital sodium (50mg/kg b.w.). Initially inferior venacava was cannulated and the liver was perfused in situ with an oxygenated Hank's buffer salt solution (HBSS; pH 7.4) containing penicillin/streptomycin $(100 \mathrm{U} / \mathrm{ml})$ at the rate of $98 \mathrm{ml} / \mathrm{min}$ for $10 \mathrm{~min} 37^{\circ} \mathrm{C}$. Liver was further perfused with oxygenated HBSS containing penicillin/streptomycin (100U/ $\mathrm{ml})$, and insulin ( $\left.1 \times 10^{-7} \mathrm{M}\right)$ followed by another perfusion with $0.04 \%$ collagenase type IV ( $\mathrm{pH}$ 7.4) for $10 \mathrm{~min}$. After perfusion the liver was gently removed and minced in HBSS containing $\mathrm{CaCl} 2(1 \mathrm{mM}), \mathrm{MgCl} 2(1 \mathrm{mM})$, penicillin/streptomycin (100U/ $\mathrm{ml})$, and insulin ( 1 x 10-7 M) (pH 7.4). The liver cell suspension was filtered with Falcon cell strainers and centrifuged at $50 \mathrm{xg}$ for $4 \mathrm{~min}$.

Rat hepatocytes were cultured in Williams medium supplemented with penicillin/streptomycin $(100 \mathrm{U} / \mathrm{ml})$ and insulin $\left(1 \times 10^{-7} \mathrm{M}\right)$ for 1-2 days and treated with $\mathrm{LOOH}$ or $\mathrm{H}_{2} \mathrm{O}_{2}$ for 4 hours. After treatments hepatocytes were scrapped from wells. Mitochondria were isolated from hepatocytes as described under, broken down by freeze and thaw followed by sonication and centrifugation at $10,000 \mathrm{x}$ g to get clear mitoplasts.

\section{Preparation of mitochondria from cultured hepatocytes}

Mitochondria from hepatocytes were isolated as described [47]. Briefly, cells were homogenized in lysis buffer $(250 \mathrm{mM}$ sucrose, $10 \mathrm{mM}$ Tris $/ \mathrm{HCl}$ (pH 7.4), 1mM EDTA, $10 \mu \mathrm{g} / \mathrm{ml}$ leupeptin, 40 komberg international units/ml aprotinin, 10 $\mu \mathrm{g} /$ $\mathrm{ml}$ pepstatin $\mathrm{A}, 0.2 \mathrm{mM}$ phenylmethylsulfonyl fluoride) and the homogenate was centrifuged at $1500 \times \mathrm{g}$ for $10 \mathrm{~min}$ at $4{ }^{\circ} \mathrm{C}$, and the supernatant was kept on ice. The pellet was re-homogenized with a further $3 \mathrm{ml}$ of isolation buffer $\left(320 \mathrm{mM}\right.$ sucrose, $1 \mathrm{mM} \mathrm{K}^{+}$-EDTA,
$10 \mathrm{mM}$ Tris- $\mathrm{HCl}, \mathrm{pH} 7.4$ ), and the homogenate was centrifuged at $1500 \times \mathrm{g}$ for $5 \mathrm{~min}$ at $4{ }^{\circ} \mathrm{C}$. The two supernatants were pooled and centrifuged at $1500 \times \mathrm{g}$ for $10 \mathrm{~min}$ at $4{ }^{\circ} \mathrm{C}$. Supernatant was further centrifuged at $17,000 \times \mathrm{g}$ for $10 \mathrm{~min}$ at $4{ }^{\circ} \mathrm{C}$. The pellet, i.e. the mitochondrial fraction, was then resuspended in $200 \mu \mathrm{l}$ of isolation buffer to obtain about $4 \mathrm{mg}$ of mitochondrial protein/ $\mathrm{ml}$. These mitochondria, incubated in PBS, were checked for their intactness and coupling by measuring the cytochrome a using $\varepsilon_{605-630 \mathrm{~nm}} 12 \mathrm{mM}-1 \mathrm{cM}^{-1}$ and by measuring transmembrane potential that is rapidly reversed by the uncoupler FCCP.

Broken mitochondria and mitoplasts were prepared by 5 times freezing the intact mitochondria in liquid nitrogen followed by thawing and sonication (3min with 30 s interval). Sonicated mitochondria were centrifuged at 25,000 x g for $10 \mathrm{~min}$ and the supernatant was used for assay of PDHC, aconitase and KGDHC activities.

\section{Preparation of LOOH (HPODE)}

Linoleic acid hydroperoxide (HPODE) was prepared by oxidation of linoleic acid by soybean lipoxidase [48]. The isolated hydroperoxide was estimated by U.V. spectrophotometry [49] using the Leukomethylene Blue assay.

\section{Assays of Mitochondrial Enzymes \\ Pyruvate dehydrogenase complex (PGDHC)}

PGDHC activity was measured spectrophotometrically using a modified method of Hinman and Blass [50] by following the formation of $\mathrm{NADH}$ at $340 \mathrm{~nm}$ at $37{ }^{\circ} \mathrm{C}$. Isolated mitochondria were resuspended in the assay buffer $(50 \mathrm{mM}$ phosphate buffer, $\mathrm{pH}$ 7.4). The reaction mixture contained the assay buffer, $0.2 \mathrm{mM}$ thiamine pyrophosphate, $1 \mathrm{mM} \mathrm{MgCl}_{2}, 2 \mathrm{mM} \mathrm{NAD}+, 0.2 \mathrm{mM}$ EGTA, $2.6 \mathrm{mM}$ L-cysteine, $0.5 \mathrm{mM} \mathrm{CaCl}_{2}, 0.3 \mathrm{mM}$ dithiotreitol, $2 \mathrm{mM}$ pyruvate, and mitochondria $(60 \mu \mathrm{g} / \mathrm{ml})$. The reaction was initiated by the addition of $0.2 \mathrm{mM}$ coenzyme A. Blank samples containing no pyruvate were included in all assays. The activity of the pyruvate dehydrogenase complex was expressed as nanomoles of NADH produced per minute per milligram of mitochondrial protein.

\section{Aconitase}

Aconitase activity was assessed by the method of Drapier JC and Hibbs (1976) [51]. The mitochondria $(60 \mu \mathrm{g} / \mathrm{ml})$ was resuspended in $100 \mathrm{mM}$ Tris- $\mathrm{HCl}$ buffer, $\mathrm{pH} 7.4$, containing $1 \mathrm{mM}$ $\mathrm{MgCl}_{2}, 1 \mathrm{mM}$ NADP, and $1 \mathrm{mM}$ potassium citrate. The reaction was started by adding isocitrate dehydrogenase $(2 \mathrm{U} / \mathrm{ml})$, carried out at $37^{\circ} \mathrm{C}$. Blank samples containing no isocitrate dehydrogenase were included in all assays. The activity of aconitase was expressed as nanomoles of NADPH formed per minute per milligram of protein.

\section{$\alpha$-Ketoglutarate dehydrogenase complex (KGDHC)}

KGDHC activity was measured according to the method of Tretter and Adam-Vizi, (2000) [52] by following the formation of $\mathrm{NADH}$ at $340 \mathrm{~nm}$ at $37^{\circ} \mathrm{C}$. Mitochondrial aliquots $(60 \mu \mathrm{g} / \mathrm{ml})$ were 
added to a $50 \mathrm{mM}$ phosphate buffer ( $\mathrm{pH} 7.4$ ) containing $0.2 \mathrm{mM}$ thiamine pyrophosphate, $1 \mathrm{mM} \mathrm{MgCl}_{2}, 2 \mathrm{mM} \mathrm{NAD}^{+}, 0.2 \mathrm{mM}$ EGTA, $2.6 \mathrm{mM}$ L-cysteine, $0.5 \mathrm{mM} \mathrm{CaCl}, 0.3 \mathrm{mM}$ dithiotreitol, and $2 \mathrm{mM}$ $\alpha$-ketoglutarate. The reaction was initiated by the addition of $0.2 \mathrm{mM}$ coenzyme A. Blank samples containing no $\alpha$-ketoglutarate were included in all assays. The activity of $\alpha$-ketoglutarate dehydrogenase complex was expressed as nanomoles of NADH produced per minute per milligram of mitochondrial protein.

\section{Statistical analysis}

Unless otherwise indicated, data are shown as mean \pm SD. Data were compared by Student's t-test. For all experiments, $\mathrm{p}<0.05$ denoted statistical significance.

\section{Results}

\section{Body and weight in diabetic mice.}

$\mathrm{Db} / \mathrm{db}$ mice displayed significantly increased body weight as compared to BKS mice (in g: $56.2 \pm 1.2$ vs. $27.5 \pm 0.4$, respectively, $\mathrm{p}<0.05$ ).

\section{Lipid peroxidation}

To assess oxidative damage in liver mitochondria, TBARS was tested. Our results showed an increase in TBARS levels in liver mitochondria of diabetic mice compared to normal mice (data not shown).

\section{Decreased activities of PDHC, aconitase and KGDHC in diabetic mice}

Next we tested the possibility that increased lipid peroxides and consequently increased oxidative stress may cause alterations in mitochondrial energy producing enzymes, making it potentially difficult to maintain energy production in mitochondria. We measured activities of liver PDHC, aconitase and KGDHC in diabetic and normal mice. Our study show decrease in activities of PDHC, aconitase and KGDHC in liver of diabetic mice compared to normal (Figure 1).

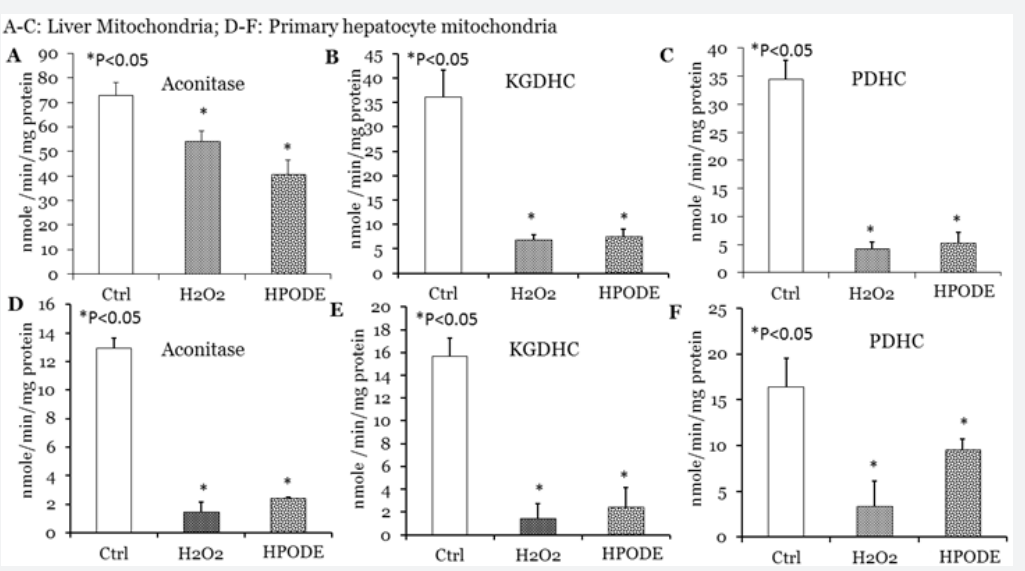

Figure 1: Decreased activities of mitochondrial enzymes upon $\mathrm{H}_{2} \mathrm{O}_{2}$ and HPODE treatment.

Decreased activities of PDHC, aconitase and KGDHC in rat liver isolated mitochondria and hepatocytes by LOOH and $\mathrm{H}_{2} \mathrm{O}_{2}$
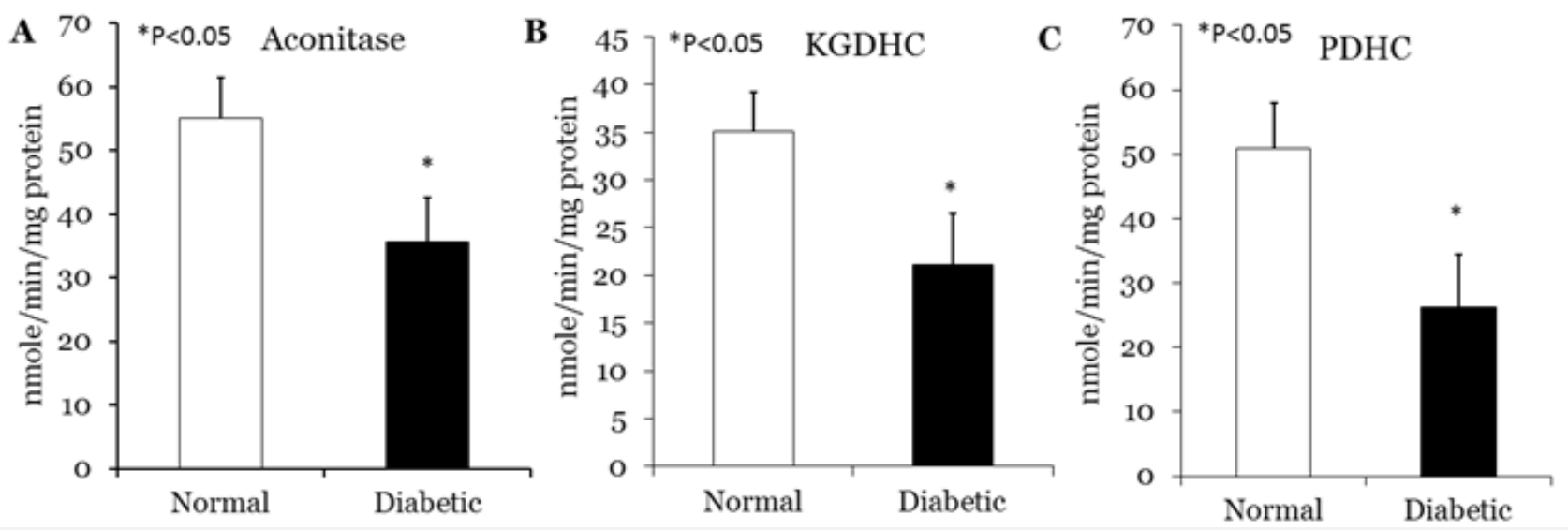

Figure 2: Reduced mitochondrial enzyme activities in diabetic mice.

In order to verify potential effects of lipid peroxides on mitochondrial energy producing enzymes, we treated isolated rat liver mitochondria with $\mathrm{LOOH}$ or $\mathrm{H}_{2} \mathrm{O}_{2}$ for $1 \mathrm{hr}$ at room temperature followed by $1 \mathrm{hr}$ in ice. Treated mitochondria were 
disrupted by freeze and thaw followed by sonication and clear homogenous liquid of mitoplasts was obtained for assay. As shown in Figure 2 treatment of mitochondria with both $\mathrm{LOOH}$ and $\mathrm{H}_{2} \mathrm{O}_{2}$ caused drastic inactivation of PDHC, aconitase and KGDHC. We further verified inactivation of these mitochondrial enzymes using cultured primary hepatocytes treated with
$\mathrm{LOOH}$ or $\mathrm{H}_{2} \mathrm{O}_{2}$. After treatment mitochondria were isolated from cells, disrupted by freeze and thaw followed by sonication for determination of enzymes activities. As shown in Figure 2, our results show a similar decrease in PDHC, aconitase and KGDHC activities in mitochondria obtained from hepatocytes.

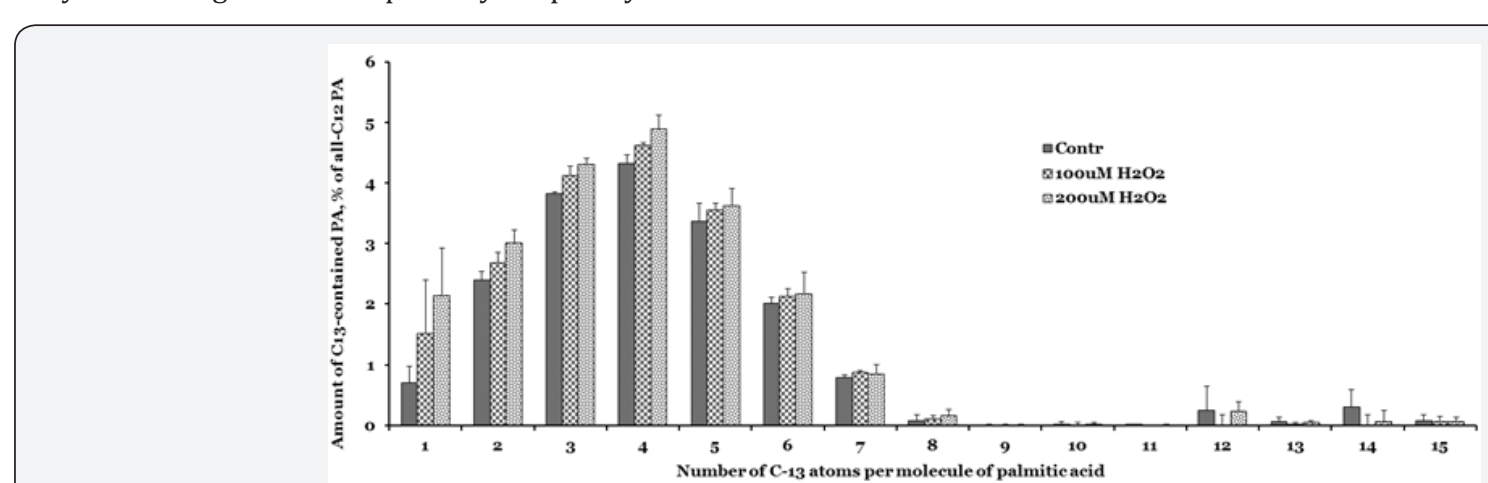

Figure 3: Incorparation of ${ }^{13} \mathrm{C}$ from acetate into palmitic acid (signal from ${ }^{13} \mathrm{C}$ sample-signal from the same ${ }^{12} \mathrm{C}$ sample).

\section{Increased fatty acid after treatment of $\mathrm{LOOH}$}

We anticipate that peroxides, in contrast to mitochondrial enzymes, would not adversely affect fatty acid synthesis in the liver cells. Cells were incubated with ${ }^{13} \mathrm{C}$-acetate in the presence of hydrogen peroxide for two hours, lipids were extracted and saponified. Tandem MS conditions were optimized with pure palmitic acid (PA). The results presented in Figure 3, shows that ${ }^{13} \mathrm{C}$-acetate was incorporated very efficiently. The number of ${ }^{13} \mathrm{C}$-atoms increased up to 4 acetate units in the $2 \mathrm{hr}$ incubation and then slowly decreased, indicating that the acetate was efficiently utilized for FA synthesis even in the presence of peroxides.

\section{Loss of pyruvate and $\mathrm{LOOH}$}

First, we tested loss of pyruvate in the presence of $\mathrm{H}_{2} \mathrm{O}_{2}$. Incubation of $50 \mathrm{mM}$ pyruvate with $50 \mathrm{mM} \mathrm{H}_{2} \mathrm{O}_{2}$ causes disappearance of pyruvate with the lapse of time. We noted a decrease of $37 \%$ to $22 \%$ with increase in incubation time from $30 \mathrm{~min}$ to $90 \mathrm{~min}$ (Figure $4 \mathrm{~A}$ ). The reaction was stoichiometric with 1:1 mole equivalents of reactants. We employed mill molar concentrations of reactants in order to follow spectrophotometric detection.

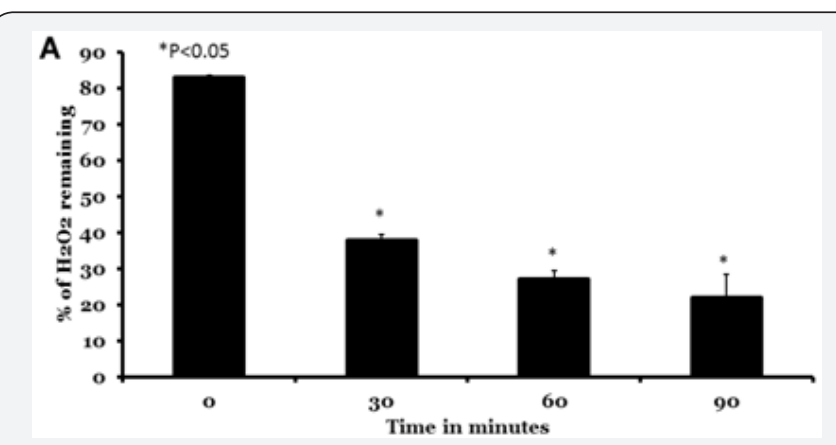

Figure 4: Loss of peroxides in presence of pyruvate Figure 4a: Reaction between $\mathrm{H}_{2} \mathrm{O}_{2}$ and pyruvic acid.
$\mathrm{LOOH}$ contains both peroxide component as well as conjugated diene structure (Figure 4B). When LOOH is reduced to $\mathrm{LOH}$, the peroxide component (as measured by LMB reaction) will be lost while the conjugated diene structure will be unaffected. Incubation of $\mathrm{LOOH}$ alone did not result in the loss of either peroxide or conjugated diene content As shown in Figure 4 , both the open and closed bars remained at $100 \%$ of the initial levels at the end of incubation. Similar incubations of $\mathrm{LOOH}$ with pyridine for $60 \mathrm{~min}$ at $37^{\circ} \mathrm{C}$ resulted in a complete loss of LMB assay activity $(\mathrm{P}<0.05)$. The levels of conjugated diene however, remained at original levels. We used acetate instead of pyruvate as control in these studies and there was no reduction in either LMB reactivity or conjugated diene in these incubations (data not shown). We used several other $\alpha$-keto acids (phenyl pyruvic acid, $\alpha$-ketoglutarate and dehydroascorbate) with result similar to that obtained using pyridine. Thus $\alpha$-ketoacids are readily decarboxylated by $\mathrm{LOOH}$ or $\mathrm{H}_{2} \mathrm{O}_{2}$ to yield acetate. As increased cytoplasmic glucose has been reported to generate increased levels of pyruvate, the results can be interpreted to suggest that increased levels of acetate might be generated when there is a oxidative stress.

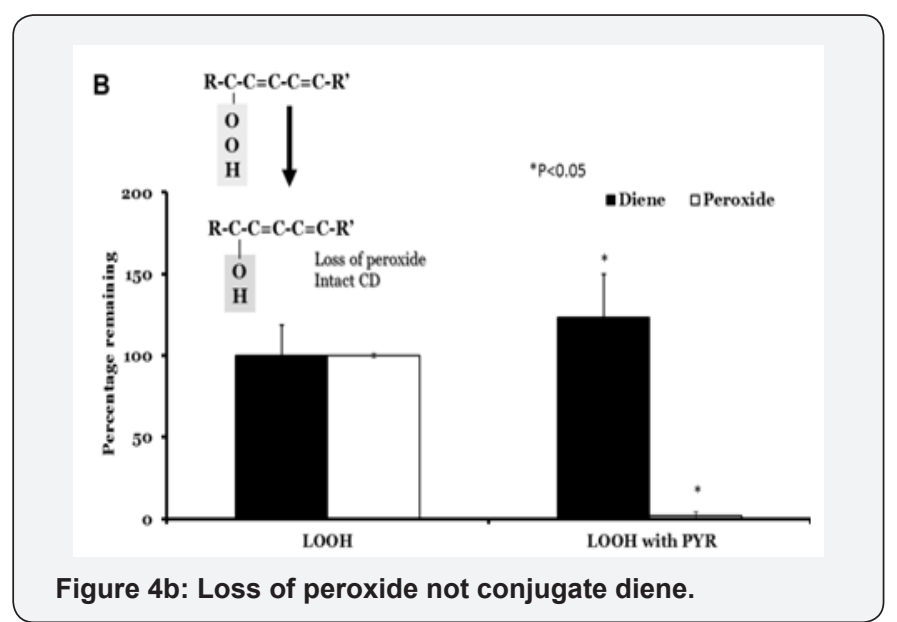




\section{Non-enzymatic conversion of pyruvate into acetate}

Next we tested non-enzymatic conversion of pyruvate into acetate [53].

\section{Release of $\mathrm{CO}_{2}$ by decarboxylation of $\alpha$-keto acids}

Carbon dioxide evolved in $\mathrm{H}_{2} \mathrm{O}_{2}$ and pyruvate reaction was measured using radioactive calcium carbonate trapping method. Pyruvate was incubated alone, with $\mathrm{H}_{2} \mathrm{O}_{2}$ or $\mathrm{H}_{2} \mathrm{O}_{2}$ alone in a vial with a cap lined with ${ }^{45} \mathrm{CaCO}_{3}$ (Figure $5 \mathrm{~A}$ ). Carbon dioxide released in experiment where pyruvate was treated with hydrogen peroxide was overwhelming (100\%) compared to pyruvate (8\%; $\mathrm{p}<0.001)$ or $\mathrm{H} 2 \mathrm{O} 2$ alone $(16 \%$; $<0.002)$. Similarly formation of carbon dioxide evolution was higher when pyruvate was treated with $\mathrm{LOOH}$ (Figure 5B) (100\%) when compared to pyruvate $(10 \% ; \mathrm{p}<0.005)$ or $\mathrm{LOOH}$ alone $(52 \%)$. The increased production of $\mathrm{CO}_{2}$ from $\mathrm{LOOH}$ alone was perplexing but interesting and reproducible. This suggest a direct peroxide mediated decarboxylation reaction. Such reactions are not unprecedented as it might suggest the formation of a per-acid step.
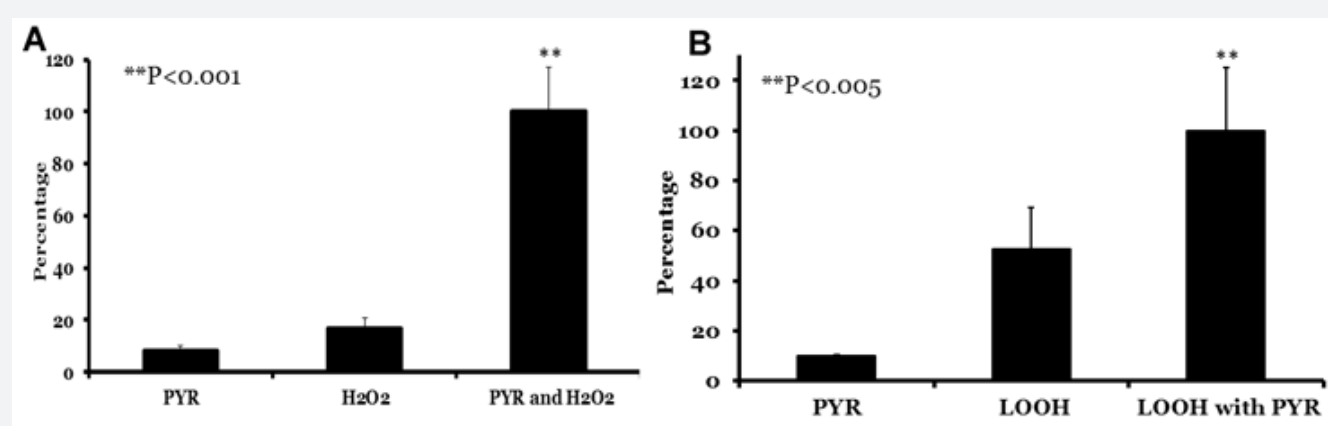

Figure 5: Release of $\mathrm{CO}_{2}$ by decarboxylation of $\alpha$-keto acids.

a) $\mathrm{CO}_{2}$ trapping with $\mathrm{Ca}(\mathrm{OH})_{2}$ using $\mathrm{H}_{2} \mathrm{O}_{2}$ b) $\mathrm{CO}_{2}$ trapping with $\mathrm{Ca}(\mathrm{OH})_{2}$ using $\mathrm{LOOH}$.

\section{Dscussion}

In this study, we establish for the first time that a mouse model of type II diabetes, $\mathrm{Db} / \mathrm{db}$ mice exhibits not only oxidative stress in liver but also inactivation of three major mitochondrial enzymes, PDHC, aconitase and KGDHC activities.

ROS production is indicated as one of the potential causes leading to insulin resistance and hepatic disease in diabetic animals [54]. For these reasons, we also assessed the oxidative status of liver mitochondria by measuring TBARS reactive substance. Our results show higher TBARS in diabetic mice that indicate an increased oxidative damage compared to normal mice. Increased ROS production in fatty liver has already been documented [55,56], and has been indicated as one of the causes rendering the liver cell more vulnerable to further injury. The main cellular site of fatty acid oxidation is the mitochondra. It is possible that excess fat deposition in the liver is partly due to alteration in mitochondrial function. Using the diabetic mice, in the present paper, we determined whether mitochondrial function is altered in the liver compared to age-matched normal mice. Increase in oxidative stress can inactivate mitochondrial enzymes. In an attempt to determine whether diabetic mice show inactivation of mitochondrial enzymes we measured PDH, aconitase and KGDHC. These dehydrogenases were chosen because the activities of these enzymes are required for the synthesis of NADH and because these enzymes have been shown to be highly susceptible to free radical-mediated inactivation. We found that all three mitochondrial enzymes are inactivated in mitochondria isolated from diabetic mice (Figure 2). A direct consequence of inactivation of key mitochondrial enzymes and increased oxidative stress as has been obtained in the present study is that all NADH producing steps in the TCA cycle are inhibited that may be reflected by dramatically reduced TCA cycle flux. These observations show that diabetic mice have lower capacity of mitochondrial NADH production. A low level of mitochondrial NADH may stimulate $\beta$-oxidation and TCA cycle flux and decrease triacylglyceride formation [57]. However, a high level of pyruvate that accumulate because of inactivation of PDHC, aconitase and KGDHC could form acetate non-enzymatically that may convert into fatty acids and triacylglycerol. Unutilized pyruvate and inactivation of mitochondrial enzymes may be related to an increase in triacylglycerols in two possible ways. First, pyruvate non-enzymatically converted to acetate and triacylglycerol and secondly, enzymes that lead to formation of free fatty acids and triacylglycerol are stable in oxidative environments in contrast to PDHC, aconitase and KGDHC that are highly susceptible to oxidative environments. Thus inactivation of mitochondrial enzymes and consequently over accumulation of pyruvate may be an alternative mechanism of triacylglycerol deposition in diabetic mice.

These diabetic mice have been reported to have higher triacylglycerols level. Under the conditions that found in those diabetic mice liver, we anticipate that treating isolated mitochondria or primary hepatocytes with $\mathrm{LOOH}$ or $\mathrm{H}_{2} \mathrm{O}_{2}$ reflect a combination of oxidative stress and increased lipid peroxides. Our study clearly show that PDH, aconitase and KGDHC are exquisitely sensitive to $\mathrm{LOOH}$ or $\mathrm{H}_{2} \mathrm{O}_{2}$.

Oxidative stress has been implicated in liver mitochondrial dysfunction in diabetic subjects [58-61]. Oxidative stress 
is associated with increases in lipid hydroperoxides, lipid peroxidation, and production of lipid peroxidation products such as and 4-hydroxy-2-nonenal (HNE) [62-64], and modification to mitochondrial protein by oxidized lipids $[65,66]$. HNE is a major product of lipid peroxidation that readily reacts with and inactivates protein [66-70]. Lipid peroxides and $\mathrm{H}_{2} \mathrm{O}_{2}$ have been viewed primarily from the perspective of the damage they may impart. It is becoming increasingly apparent, however, that by virtue of the ability to alter protein function [71] they can modify mitochondrial functions. To determine whether observed declines in mitochondrial enzymes could, at least in part, due to increased reactive oxygen species or oxidized lipids, mitochondria were isolated from perfused rat liver and treated with $\mathrm{LOOH}$ or $\mathrm{H}_{2} \mathrm{O}_{2}$. The inactivation of enzyme was then determined after two hours of incubation. As shown in Figure 2, PDH, aconitase and KGDHC activities are drastically inhibited with $\mathrm{LOOH}$ and $\mathrm{H}_{2} \mathrm{O}_{2}$. We further verified these results in primary hepatocytes treated with $\mathrm{LOOH}$ or $\mathrm{H}_{2} \mathrm{O}_{2}$. Our results show similar results in mitochondria isolated with hepatocytes treated with $\mathrm{LOOH}$ or $\mathrm{H}_{2} \mathrm{O}_{2}$. Based on results presented in Figure 2, we conclude that inactivation of PDH, aconitase and KGDHC could affect supply of NADH to the electron transport chain that controls the rate of NADH-linked mitochondrial respiration. The results of this study indicate that, $\mathrm{LOOH}$ and $\mathrm{H}_{2} \mathrm{O}_{2}$ interact with $\mathrm{PDH}$, aconitase and KGDHC resulting in enzyme inactivation.

Previous studies showed the susceptibility of aconitase to free radical inactivation [72-76]. Aconitase contains an active site iron-sulfur $[4 \mathrm{Fe}-4 \mathrm{~S}]^{2+}$ complex. Using electronic spin resonance, it was determined that when purified mitochondrial aconitase is treated with superoxide the $(4 \mathrm{Fe}-4 \mathrm{~S})^{2+}$ cluster is oxidized to $(3 \mathrm{Fe}-4 \mathrm{~S})^{1+}$, resulting in the release of $\mathrm{Fe}(\mathrm{II})$ and $\mathrm{H}_{2} \mathrm{O}_{2}$ [77]. Similarly KGDHC is also very susceptible to oxidative species. In vitro studies show that lipid peroxidation and lipid peroxidation products induced inactivation of KGDHC involves modification of essential lipoic acid residues covalently linked to E2 subunits of the enzyme [78]. One consequence of inactivation of KGDHC may be oxidation of glutamate by glutamate dehydrogenase that result in the accumulation of $\alpha$-ketoglutarate. The conversion of glutamate to $\alpha$-ketoglutarate by glutamate dehydrogenase is thermodynamically unfavorable $\left(\mathrm{K}_{\mathrm{eq}}=1.8 \times 10^{-13}\right)$, and a buildup of $\alpha$-ketoglutarate would be expected to reduce the rate of glutamate utilization. In addition, pyruvate dehydrogenase, an enzyme that shares structural and functional similarities with $\mathrm{KGDH}$ and contains covalently bound lipoic acid residues [79], may exhibit a similar response to $\mathrm{LOOH}$ or $\mathrm{H}_{2} \mathrm{O}_{2}$ inactivation. Together inactivation of these mitochondrial enzymes in diabetic mice as well as in vitro experiments in isolated mitochondria and hepatocytes treated with $\mathrm{LOOH}$ or $\mathrm{H}_{2} \mathrm{O}_{2}$ suggesting impairment of NADH production.

During the course of present study, we noted an increase of ${ }^{13} \mathrm{C}$ acetate as detected by ${ }^{13} \mathrm{C} \mathrm{LC} / \mathrm{MS}$ of the hepatocytes treated with $\mathrm{LOOH}$ or $\mathrm{H}_{2} \mathrm{O}_{2}$. The impact of $\mathrm{LOOH}$ or $\mathrm{H}_{z} \mathrm{O}_{2}$ on increase in the fatty acid concentration is a direct reflection of its importance as a catastrophic pathway that lead to accumulation of triacylglycerols in the tissue. Under normal conditions, fatty acid synthesis and fatty acid oxidation must always balanced. However, with the inactivation of PDH, aconitase and KGDHC, pyruvate and TCA cycle intermediates may accumulate. Increase in these intermediates may cause allosteric inhibition of TCA cycle activity and fatty acid oxidation [80].

Thus, inactivation of PDHC, aconitase and KGDHC appears to be the primary mechanism by which $\mathrm{LOOH}$ or $\mathrm{H}_{2} \mathrm{O}_{2}$ may cause an increase in free fatty acids and triacylglycerols in tissues. Because the diabetic mice has more oxidative stress as shown by increased TBARS substances, therefore these mice would be expected to be more sensitive to mitochondrial enzyme inactivation.

It is noteworthy that, under the conditions of our experiments, the magnitude to which $\mathrm{PDH}$, aconitase and $\mathrm{KGDH}$ were inactivated was similar, regardless of the concentration of LOOH or $\mathrm{H}_{2} \mathrm{O}_{2}$ utilized (data not shown).

\section{Conclusion}

Maintenance of mitochondrial function depends on the ability of mitochondria to sense changes in redox status and respond in a manner commensurate with metabolic requirements. In this study, we have provided clear evidence that overall mitochondrial enzymes are inactivated by the addition of $\mathrm{LOOH}$ and $\mathrm{H}_{2} \mathrm{O}_{2}$ that promotes formation of fatty acids and triacylglycerols in a switch over mechanism from catabolic pathway to anabolic pathway. Whereas these observations suggest a role of oxidative stress in the liver mitochondrial impairments, this study points out a mechanisms whereby mitochondrial enzyme inactivation leads to formation of free fatty acids and triacylglycerols in diabetic subjects. In addition, experiments designed to test the effects of exogenously added $\mathrm{LOOH}$ and $\mathrm{H}_{2} \mathrm{O}_{2}$ will further enhance our understanding of the process and its physiological significance. In conclusion, our results indicate that alterations in the mitochondrial enzymes induced by $\mathrm{LOOH}$ or $\mathrm{H}_{2} \mathrm{O}_{2}$ are associated with the ectopic fat storage in the liver. Although this association cannot distinguish between causes and effects, it is interesting that our results fit with the emerging idea that mitochondrial dysfunction can lead to the development of metabolic diseases, such as obesity, type 2 diabetes mellitus. These results suggest that $\mathrm{LOOH}$ or $\mathrm{H}_{2} \mathrm{O}_{2}$ production may serve to regulate mitochondrial function.

\section{References}

1. Oberley LW (1988) Free radicals and diabetes. Free Radic Biol Med 5(2): 113-124.

2. Baynes JW (1991) Role of oxidative stress in development of complications in diabetes. Diabetes 40(4): 405-412.

3. Wolff SP, Jiang ZY, Hunt JV (1991) Protein glycation and oxidative stress in diabetes mellitus and ageing. Free Radic Biol Med 10(5): 339-352.

4. Baynes JW, Thorpe SR (1999) Role of oxidative stress in diabetic complications: a new perspective on an old paradigm. Diabetes 48(1): $1-9$. 
5. Altomare E, Vendemiale G, Chicco D, Procacci V, Cirelli F (1992) Increased lipid peroxidation in type 2 poorly controlled diabetic patients. Diabetes \& Metabolism 18(4): 264-271.

6. Gallou G, Ruelland A, Legras B, Maugendre D, Allannic H, Cloarec L (1993) Plasma malondialdehyde in type 1 and type 2 diabetic patients. Clin Chim Acta 214(2): 227-234.

7. Van Dam PS, Bravenboer B (1997) Oxidative stress and antioxidant treatment in diabetic neuropathy. Neuroscience Research Communications 21(1): 41-48.

8. Santos MS, Santos DL, Palmeira CM, Seica R, Moreno AJ, et al. (2001) Brain and liver mitochondria isolated from diabetic Goto-Kakizaki rats show different susceptibility to induced oxidative stress. Diabetes Metab Res Rev 17(3): 223-230.

9. Hall JC, Sordahl LA, Stefko PL (1960) The Effect of Insulin on Oxidative Phosphorylation in Normal and Diabetic Mitochondria. J Biol Chem 235: 1536-1539.

10. Wallace DC (1992) Mitochondrial Genetics: A Paradigm for Aging and Degenerative Diseases? Science 256(5057): 628-632.

11. Sukalski KA, Pinto KA, Berntson JL (1993) Decreased Susceptibility of Liver Mitochondria From Diabetic Rats to Oxidative Damage and Associated Increase in Alpha-Tocopherol. Free Radic Biol Med 14(1): 57-65.

12. Kristal BS, Matsuda M, Yu BP (1996) Abnormalities in the mitochondrial permeability transition in diabetic rats. Biochem. Biophys Res Commun 222(2): 519-523.

13. Schrauwen P, Hesselink MK (2004) Oxidative capacity, lipotoxicity, and mitochondrial damage in type 2 diabetes. Diabetes 53(6): 1412-1417.

14. Kelley DE, He J, Menshikova EV, Ritov VB (2002) Dysfunction of mitochondria in human skeletal muscle in type 2 diabetes. Diabetes 51(10): 2944-2950.

15. Kelley DE, Simoneau JA (1994) Impaired free fatty acid utilization by skeletal muscle in non-insulin-dependent diabetes mellitus. J Clin Invest 94(6): 2349-2356.

16. Touyz RM, Schiffrin EL (2004) Reactive oxygen species in vascular biology: implications in hypertension. Histochem Cell Biol 122(4): 339-352.

17. Deedwania PC, Fonseca VA (2005) Diabetes, prediabetes, and cardiovascular risk: shifting the paradigm. Am J Med 118(9): 939-947.

18. Ames BN, Shigenaga MK and Hagen TM (1993) Oxidants, antioxidants, and the degenerative diseases of aging. Proc Natl Acad Sci USA 90(17): 7915-7922.

19. Cortopassi GA, Wong A (1999) Mitochondria in organismal aging and degeneration. Biochim Biophys Acta 1410(2): 183-193.

20. Nohl H (1994) Generation of superoxide radicals as byproduct of cellular respiration. Ann Biol Clin (Paris) 52(3): 199-204.

21. Nohl H, Gille L, Staniek K (1997) Endogenous and exogenous regulation of redox-properties of coenzyme Q. Mol Aspects Med 18 Suppl: S33-S40.

22. Giugliano D, Ceriello A, Paolisso G (1995) Diabetes mellitus, hypertension, and cardiovascular disease: which role for oxidative stress? Metabolism 44(3): 363-368.

23. Mullarkey CJ, Edelstein D, Brownee M (1990) Free radical generation by early glycation products: A mechanism for accelerated atherogenesis in diabetes. Biochem Biophys Res Commun 173(3): 932-939.

24. Schleicher ED, Wagner E, and Nerlich AG (1997) Increased accumulation of the glycoxidation product $\mathrm{N}$ (epsilon)-(carboxymethyl)lysine in human tissues in diabetes and aging. J Clin Invest 99(3): 457-468.

25. Tesfamariam B (1994) Free radicals in diabetic endothelial cell dysfunction. Free Radic Biol Med 16(3): 383-391.
26. Yan SD, Schmidt AM, Anderson G, Zhang J, Brett J, et al. (1994) Enhanced cellular oxidant stress by the interaction of advanced glycation endproducts with their receptors/binding proteins. J Biol Chem 269(13): 9889-9897.

27. Tesfamariam B, Cohen RA (1992) Free radicals mediate endothelial cell dysfunction caused by elevated glucose. Am J Physiol 263(2 Pt 2): H321-H326.

28. Williamson JR, Chang K, Frangos M, Hasan KS, Ido Y, et al. (1993) Hyperglycemic pseudohypoxia and diabetic complications. Diabetes 42(6): 801-813.

29. Griendling KK, Minieri CA, Ollerenshaw JD, Alexander RW (1994) Angiotensin II stimulates NADH and NADPH oxidase activity in cultured vascular smooth muscle cells. Circ Res 74(6): 1141-1148.

30. Graier WF, Simecek S, Kukovetz WR, Kostner GM (1996) High D-Glucose-Induced Changes in Endothelial Ca2+/EDRF Signaling are Due to Generation of Superoxide Anions. Diabetes 45(10): 1386-1395.

31. Cosentino F, Hishikawa K, Katusic ZS, Lüscher TF (1997) High glucose increases nitric oxide synthase expression and superoxide anion generation in human aortic endothelial cells. Circulation 96(1): 25-28.

32. Giugliano D, Acampora R, Marfella R, De Rosa N, Ziccardi P, et al. (1997) Metabolic and cardiovascular effects of carvedilol and atenolol in noninsulin-dependent diabetes mellitus and hypertension. A randomized, controlled trial. Ann Intern Med 126(12): 955-959.

33. Laaksonen DE, Atalay M, Niskanen L, Uusitupa M, Hanninen O, et al. (1996) Increased resting and exercise-induced oxidative stress in young IDDM men. Diabetes Care 19(6): 569-574.

34. Reaven GM (1995) Pathophysiology of insulin resistance in human disease. Physiol Rev 75(3): 473-486.

35. Miguel AA, Niraj Bhatt, Sonia CC (2014) Mitochondrial and cellular mechanisms for managing lipid excess Front Physiol 5: 282.

36. Gibson JM, Westwood M, Lauszus FF, Klebe JG, Flyvbjerg A, et al. (1999) Phosphorylated insulin-like growth factor binding protein 1 is increased in pregnant diabetic subjects. Diabetes 48(2): 321-326.

37. Richards EM, Rosenthal RE, Kristian T, Fiskum G (2006) Postischemic hyperoxia reduces hippocampal pyruvate dehydrogenase activity. Free Radic Biol Med 40(11): 1960-1970.

38. Lucas DT, Szweda LI (1999) Declines in mitochondrial respiration during cardiac reperfusion: Age-dependent inactivation of a -ketoglutarate dehydrogenase Proc Natl Acad Sci USA 96(12): 66896693.

39. Pitula JS, Deck KM, Clarke SL, Anderson SA, Vasanthakumar A, et al. (2004) Selective inhibition of the citrate-to-isocitrate reaction of cytosolic aconitase by phosphomimetic mutation of serine-711. Proc Natl Acad Sci USA 101(30): 10907-10912.

40. Castro L, Rodriguez M, Radif R (1994) Aconitase Is Readily Inactivated by Peroxynitrite, but Not by Its Precursor, Nitric Oxide. The Journal of Biological chemistry 269(47): 29409-29415.

41. Muller FL, Liu Y, Remmen HV (2004) Complex III Releases Superoxide to Both Sides of the Inner Mitochondrial Membrane J Biol Chem 279(47): 49064-49073.

42. Nulton-Persson AC, Szweda L (2001) Modulation of mitochondrial function by hydrogen peroxide. J Biol Chem 276(26): 23357-23361.

43. Duchen MR (2004) Roles of mitochondria in health and disease. Diabetes 53(Suppl 1): S96-S102.

44. Mastrocola R, Restivo F, Vercellinatto I, Danni O, Brignardello E, et al. (2005) Oxidative and nitrosative stress in brain mitochondria of diabetic rats. J Endocrinol 187(1): 37-44.

45. Parihar MS, Nazarewicz RR, Kincaid E, Bringold U, Ghafourifar P (2008) Association of mitochondrial nitric oxide synthase activity with 
respiratory chain complex I. Biochem Biophys Res Commun 366(1): 23-28.

46. Bradford MM (1976) A rapid and sensitive method for the quantitation of microgram quantities of protein utilizing the principle of proteindye binding. Anal Biochem 72: 248-254.

47. Parihar MS, Parihar A, Fujita M, Hashimoto M, Ghafourifar P (2008) Mitochondrial association of alpha-synuclein causes oxidative stress. Cell Mol Life Sci 65(7-8): 1272-1284.

48. Khan-Merchant N, Penumetcha M, Meilhac O, Parthasarathy S (2002) Oxidized fatty acids promote atherosclerosis only in the presence of dietary cholesterol in low-density lipoprotein receptor knockout mice. J Nutr 132(11): 3256-3262.

49. Auerbach BJ, Kiely JS, Cornicelli JA (1992) A spectrophotometric microtiter-based assay for the detection of hydroperoxy derivatives of linoleic acid. Anal Biochem 201(2): 375-380.

50. Hinman LM, Blass JP (1981) An NADH-linked spectrophotometric assay for pyruvate dehydrogenase complex in crude tissue homogenates. J Biol Chem 256(13): 6583-6586.

51. Drapier JC, Hibbs JB (1986) Murine cytotoxic activated macrophages inhibit aconitase in tumor cells. Inhibition involves the iron-sulfur prosthetic group and is reversible. J Clin Invest 78(3): 790-797.

52. Tretter L, Adam-Vizi V (2000) Inhibition of Krebs Cycle Enzymes by Hydrogen Peroxide: A Key Role of $\alpha$-Ketoglutarate Dehydrogenase in Limiting NADH Production under Oxidative Stress. J Neurosci 20(24) 8972-8979.

53. Raghavamenon A, Garelnabi M, Babu S, Aldrich A, Litvinov D et al (2009) $\alpha$-Tocopherol Is Ineffective in Preventing the Decomposition of Preformed Lipid Peroxides and May Promote the Accumulation of Toxic Aldehydes: A Potential Explanation for the Failure of Antioxidants to Affect Human Atherosclerosis. Antioxid Redox Signal 11(6): 1237 1248.

54. Kim J, Wei YZ, James R (2008) Sowers Role of Mitochondrial Dysfunction in Insulin Resistance. Circ Res 102(4): 401-414 Raghavamenon A Garelnabi M, Babu S, Aldrich A, Litvinov D, et al. (2009) $\alpha$-Tocopherol is Ineffective in Preventing the Decomposition of Preformed Lipid Peroxides and May Promote the Accumulation of Toxic Aldehydes: A Potential Explanation for the Failure of Antioxidants to Affect Human Atherosclerosis. Antioxid Redox Signal 11(6): 1237-1248.

55. Wei YZ, Rector RS, Thyfault JP, Ibdah JA (2008) Nonalcoholic fatty liver disease and mitochondrial dysfunction World J Gastroenterol 14(2): 193-199.

56. Freitas I, Boncompagni E, Tarantola E, Gruppi C, Bertone V, et al. (2016) In Situ Evaluation of Oxidative Stress in Rat Fatty Liver Induced by a Methionine- and Choline-Deficient Diet. Oxidative Medicine and Cellular Longevity 2016: 1-14.

57. Eaton S (2002) Control of mitochondrial $\beta$-oxidation flux. Prog Lipid Res 41(13): 197-239.

58. Jacobson TA, Miller M, Schaefer EJ (2007) Hypertriglyceridemia and cardiovascular risk reduction. Clin Ther 29(5): 763-777.

59. Ginsberg HN, Huang LS (2000) The insulin resistance syndrome: impact on lipoprotein metabolism and atherothrombosis. J Cardiovasc Risk 7(5): 325-331.

60. Rizzo M, Rini GB, Berneis K (2007) The Clinical Relevance of LDL Size and Subclasses Modulation in Patients with Type-2 Diabetes. Exp Clin Endocrinol Diabetes 115(8): 477-482.

61. Ginsberg HN, Zhang YL, Hernandez-Ono A (2005) Regulation of plasma triglycerides in insulin resistance and diabetes. Arch Med Res 36(3): 232-240.

62. Sato Y, Hotta N, Sakamotto N, Matsuoka S, Oshini N, et al. (1979) Lipid peroxide level in plasma of diabetic patients. Biochemistry 21(1): 104-
107.

63. Frankel EN, Neff WE (1983) Formation of malonaldehyde from lipid oxidation products. Biochim Biophys Acta 754(3): 264-270.

64. Dranka BP, Benavides GA, Diers AR, Giordano S, Zelickson BR, et al. (2011) Assessing bioenergetic function in response to oxidative stress by metabolic profiling. Free Radic Biol Med 151(9): 1621-1635.

65. Masaki H, Okano Y, Sakurai H (1997) Generation of active oxygen species from advanced glycation end products (AGE) under ultraviolet light A (UVA) irradiation. Biochem Biophys Res Commun 235(2): 306310.

66. Schmidt AM, Hori O, Brett J, Yan SD, Wautier JL, et al. (1994) Cellular receptors for advanced glycation end products. Implications for induction of oxidant stress and cellular dysfunction in the pathogenesis of vascular lesions. Arterioscler Thromb 14(10): 1521-1528.

67. Esterbauer H, Schaur RJ, Zollner H (1991) Chemistry and biochemistry of 4-hydroxynonenal, malonaldehyde and related aldehydes. Free Radic Biol Med 11(1): 81-128.

68. Chen JJ, Bertrand H, Yu BP (1995) Inhibition of adenine nucleotide translocator by lipid peroxidation products. Free Radic Biol Med 19(5): 583-590.

69. Szweda LI, Uchida K, Tsai L, Stadtman ER (1993) Inactivation of glucose6-phosphate dehydrogenase by 4-hydroxy-2-nonenal. Selective modification of an active-site lysine. J Biol Chem 268(5): 3342-3347.

70. Uchida K, Stadtman ER (1993) Covalent attachment of 4-hydroxynonenal to glyceraldehyde-3-phosphate dehydrogenase. A possible involvement of intra- and intermolecular cross-linking reaction. J Biol Chem 268(9): 6388-6393.

71. Berlett BS, Stadtman ER (1997) Protein oxidation in aging, disease, and oxidative stress. J Biol Chem 272(33): 20313-20316.

72. Hausladen A, Fridovich I (1994) Superoxide and peroxynitrite inactivate aconitases, but nitric oxide does not. J Biol Chem 269(47): 29405-29408.

73. Janero DR, Hreniuk D (1996) Suppression of TCA cycle activity in the cardiac muscle cell by hydroperoxide-induced oxidant stress. Am J Physiol Cell Physiol 270(6Pt 1): C1735-C1742.

74. Verniquet F, Gaillard J, Neuburger M, Douce R (1991) Rapid inactivation of plant aconitase by hydrogen peroxide. Biochem J 276(Pt 3): 643-648.

75. Emptage MH (1988) Metal Clusters in Proteins. American Chemical Society, Washington, DC, USA, p. 343.

76. Tong J, Feinberg BA (1994) Direct square wave voltametry of supoeroxidized [4Fe-4S]3+ aconitase and associated $3 \mathrm{Fe} / 4 \mathrm{Fe}$ cluster intercnverstions. J Biol Chem 269(40): 24920-24927.

77. Vásquez-Vivar J, Kalyanaraman B, Martásek P, Hogg N, Masters BS, et al. (1998) Superoxide generation by endothelial nitric oxide synthase. The influence of cofactors. Proc Natl Acad Sci USA 95(16): 9220-9225.

78. Humphries KM, Szweda L (1998) Selective inactivation of alphaketoglutarate dehydrogenase and pyruvate dehydrogenase: reaction of lipoic acid with 4-hydroxy-2-nonenal. Biochemistry 37(45): 1583515841.

79. Perham RN (1991) Domains, motifs, and linkers in 2-oxo dehydrogenase multienzyme complexes; A paradigm in the design of a multi-functional protein. Biochemistry 30(35): 8501-8512.

80. Burgess S Hausler C, Merritt N, Jeffrey M, Storey FM, Milde C, et al. (2004) Impaired tricarboxylic acid cycle activity in mouse livers lacking cytosolic phosphoenolpyruvate carboxykinase. J Biol Chem 279(47): 48941-48949. 
Your next submission with Juniper Publishers will reach you the below assets

- Quality Editorial service

- Swift Peer Review

- Reprints availability

- E-prints Service

- Manuscript Podcast for convenient understanding

- Global attainment for your research

- Manuscript accessibility in different formats

(Pdf, E-pub, Full Text, Audio)

- Unceasing customer service

Track the below URL for one-step submission https://juniperpublishers.com/online-submission.php 